\title{
Science, politics and policymaking
}

\author{
Even though expert knowledge has become indispensible for policymaking, providing scientific advice to \\ governments is not always easy
}

\author{
Anthony King
}

$\mathrm{D}$ uring the Brexit referendum, a British politician made a now notorious quip about people having "enough of experts”. Yet evidence-based decisionmaking has become a byword for good governance. Many challenges demand input from experts, with almost every government arm having a science angle, be it in fisheries, agriculture, transport or drug policy. Scientific advice is crucial to deal with emergencies such as the Ebola or Zika outbreaks and for addressing long-term threats such as food supply, water shortages or climate change. "Every department crosses over into science. It's just like finance really: you need money for everything”, said Frank Gannon, Director of the QIMR Berghofer Medical Research Institute in Brisbane, Australia, and former Director of EMBO and Science Foundation Ireland. He thus believes that formal structures that provide expert advice to government are necessary, because otherwise "you are likely to pick up somebody's opinion that may have a self-interest, overtly or covertly".

\section{A troubled relationship}

However, the liaison between scientists and governments is not always a happy one. Researchers often complain about politicians cherry picking evidence to support particular policy decisions or policymakers who do not understand or act upon the correct evidence. Some advisors have even had bruising experiences at the coalface of policymaking. "When I started, I was under the impression that scientific advice would be listened to", recalled David Nutt, psycho-pharmacologist at Imperial College London, UK, who was sacked from the UK's Advisory Council of the Misuse of Drugs in 2009 after clashing with politicians over drug harm and classification. Memorably, he noted horse riding was more risky than taking ecstasy. He argued that illicit drugs should be classified according to actual evidence of harm and dependence, which would rate alcohol above ecstasy and cannabis.

\section{"... the liaison between scientists and governments is not always a happy one"}

Nutt commented that the government's approach to drug policy was guided by the Home Office, rather than the health department. "If you said something they wanted to hear, they loved it. If not, they ignored it. There were never any concessions". The topsy-turvy attitude was summed up, he said, by one minister who, when asked by a parliamentary committee if he understood the evidence, answered: "Evidence is what we look for to support our policy decisions". Nutt's experience was so negative that he goes so far as to say: "I'm a meritocrat. I would put scientists in charge. I don't think we need politicians".

\section{A slow process}

Nonetheless, acting on scientific advice is not always a straightforward process. Policymakers are often confronted with making big decisions in a fog of uncertainty owing to limited information, and ambiguity due to the many ways a policy problem can be understood. Scientists in turn can harbour false expectations. "Scientists often extrapolate from the scientific method to policy. They think it is a formal process by which a problem is identified, analysed, an action proposed and conclusions reached", said Peter Gluckman, paediatrician and chief scientific advisor to the prime minister of New Zealand. "It's a much messier and [more] complicated process than that". He knocks down false notions that scientific evidence can by itself directly influence policy outcome. "Science is only part of the policymaking process”, Gluckman emphasized. "Science can put what we know on the table and acknowledge that that leads to a variety of options. Government will then consider public opinion, electoral contests, fiscal priorities, and so forth".

In his recent book The Politics of Evidence-Based Policymaking, Paul Cairney, Professor of Politics and Public Policy at Stirling University, UK, writes that scientists need to accept that policymaking does not work like the scientific method. "People seeking to inject more scientific evidence into policymaking may not be paying enough attention to the science of policymaking", he wrote. "Scientists should identify how the policy process works and seek to influence it on that basis, not according to how they would like it to be".

Cairney cited tobacco control as an example of how evidence slowly translates into policy. Initial studies that showed that smoking causes cancer were published in the 1950 s, yet it took a decade to become accepted in the medical profession and longer for politicians to introduce policies to curb smoking. The delay was not just due to a lack of evidence. Instead, public health advocates had to build alliances, challenge vested interests, encourage social change, shift policymaking to more sympathetic departments and persuade governments to rethink how they looked at the issue. The use of evidence in policy is tied to the 
environment in which policy choices are made. "Go back fifty years and no government would have survived increasing tax on cigarettes by $500 \%$, banning them in public places or insisting on plain packages, because smoking was so central to society", Gluckman said. "The solutions have to work in the political and policy domain as well. There are lots of situations where governments ignore or discount evidence, often because the evidence is uncertain. And remember the science of today informs the policy of tomorrow, but the science of yesterday informs the policy of today".

\section{“ ... scientists need to accept that policymaking does not work like the scientific method"}

Politicians want certainty and solutions, while scientists often deal in probabilities. "Some talk about needing policy makers that are more scientifically literate, but the idea that the solution is to get policy makers to think more like scientists is extremely naive", Cairney warned. Moreover, evidence has different meanings. "Evidence to a policy maker is not the same as evidence to a scientist", noted Gluckman. "Anecdote is important or probably more impressive than structured evidence to many policy makers". An emotive photograph that distils an issue can fire up political action better than a long-winded policy document or a randomized control trial. Decisions are based on a mixture of emotions, knowledge and shortcuts to gather evidence.

\section{GMOS, torture and transparency}

These issues are highly visible in the ongoing debate regarding genetically modified crops that leaves many scientists frustrated. It was an issue that embattled Anne Glover in Brussels during her time as chief science advisor to the president of the European Commission. "There is no evidence to tell us that GM crops are any less safe than any other form of commercialized crops we currently use”, she said. Still she cautions scientists against straying into policymaking. "An advisor doesn't make policy and is not political. All you are doing is finding the best evidence", said Glover, who became the first science advisor to Scotland in 2006 and is now at the University of Aberdeen, UK.

She criticized Scotland's decision last year to ban GM crops, but not because they ignored the evidence. Rather, she criticized them for saying there was not enough evidence to show they were safe (when there was) and that evidence showed a ban would give Scotland an economic advantage (when there was none). "That is not a fair explanation of the evidence”, Glover said. She therefore argues strongly for more transparency in terms of advice and did so during her time at the Commission too. "We often don't know what evidence was used and what evidence was rejected and why and that is important. Transparency is crucial, because without it you don't have trust", Glover explained. "You may decide that though the evidence tells you to do A, you do B, and so ignore the evidence. As a scientist, I am happy with that, as long as an explanation is given and it is transparent".

Others agree. "Policymakers should be able to justify their decisions", commented Julian Kinderlerer, a former professor of biotechnology and now emeritus professor of intellectual property law and policy at the University of Cape Town, South African. He supported Nutt's decision to step out of line and tell the government publicly that it was wrong. "Otherwise we would not know that government policy was not based on the advice of that committee and that would be bad. It is better to speak out and be heard". Kinderlerer also pointed to the secret legal and ethical justification given to the Bush administration by American psychologists that helped justify torture. Advice given to governments should be open, and scientists working in industry, NGOs or special interest groups such as those for patients, should feed into the process, not just high-level scientific advisors. Gluckman added some caution: His chats with the prime minister can rarely be put in an official record-but that does not happen with other advisors.

\section{Arguing worldviews, not science}

Yet, scientists are not faultless either. Like many experienced scientific advisors, Kinderlerer is critical of the deficit model too often adopted by scientists: Trust me, I am a scientist. Another fault is that the purveyors of advice are sometimes advocates who wear a false mask of neutrality. Some believe that experts who falsely posed as impartial knowledge brokers contributed to a loss of trust in the recent Brexit referendum in the UK. "Some use science as a proxy for a debate that is not scientific", Gluckman said. "When they don't admit to the unknowns and allow their own personal advocacy to take over, then they usurp the role of policy makers and policy makers will over react to that".

GMOs and climate change are case studies where ideology has usurped the debate. The science of anthropogenic climate change has been reasonably solid for a long time, but the debates are really value debates, Gluckman said. Action on climate change brings contentious issues such as intergenerational equity and north-south equity that cannot be solved with mere evidence. "Some ask why should this generation make economic sacrifices for the benefit of later generations when we can wait and see what happens, because there is some uncertainty, and besides, technology will solve it sooner or later", Gluckman noted, "versus those who take the view the risk is so high that we must move now". For GMOs, the debate is about the role of big companies in the food industry and interference with nature. "This is more of a philosophical debate”, Gluckman concluded. "You cannot expect science to resolve fundamentally different world views".

Moreover, the way to understand a problem in the first place can influence what evidence may be relevant. If mulling over fracking, a policymaker might ask a geologist whether the concern is about safety, or a public health scientist whether its health or an economist whether it is the cost of energy in future. "The argument then is not about the evidence, because first you must have your argument about values and aims”, Cairney said.

cc "... the way to understand a problem in the first place can influence what evidence may be relevant"

Regarding the GM ban in Scotland, Cairney would therefore counsel scientists against complaining that policymakers overstated the risks or do not understand the science. "Let us do enough research on a small scale or ask a minister how to demonstrate that the risk is low enough for your satisfaction. Then, go do the research. So 
agree that a decision has been made in the short term, but agree on what would change their mind in the long term", he advised.

\section{A complex process}

He also advised scientists not to bombard policymakers with information. "You are entering an arena where you must tell people what the problem is, why they should care and what the solution is, all in a very short time or a few hundred words". Find out what policymakers care about and frame the evidence in those terms. Many government science advisors quickly develop a political antenna and learn how best to communicate the science. Though Gluckman was adamant that the role is misnamed, "I am not advising on science. I am advising on the use of science".

Those in advisory positions also point out that there is an entire ecosystem of advice for policymakers, with overlap between the influencer and deciders, which leaves room for scientists to become influencers at all levels. "It is not a simple linear process, so a single interaction doesn't make for evidence-informed policymaking”, Gluckman said. Glover said she was initially surprised by the complexity of the European Commission in terms of how it works. "People were proud of existing structures and activities and did not necessarily want someone else to come in and be a critical friend, because that is what a chief advisor can be", she said. Others have had a similar experience. "The Commission has a hard time accepting advice from the outside, I'm sorry to say. But I saw it clearly when we started with the European Research Council”, said Ernst-Ludwig Winnacker, who was its President when it began in 2007. Cairney therefore recommends that scientists wanting to offer advice, identify where action takes place or seek out allies and learn how to frame evidence to fit policy agendas.

\section{cc ... even in the most enlightened democracies, scientists should not kid themselves in thinking they can win the day with mere evidence"}

There is, nonetheless, a general trend in Europe towards more formal scientific advice. When Glover began at the Commission, only three EU member states had a chief scientific advisor; when she left, 14 states had someone in place. "We are seeing various institutions being put in place, not only chief science advisors but a whole range of intermediary structures, such as SAM [a committee structure] now in the EU”, noted James Wilsdon, science policy expert at the University of Sheffield, UK. "There is progress toward a more established recognition of evidence and expertise in policy systems, but at the same time one doesn't have to look far to see countervailing forces and trends”.

\section{Natural tension}

"Politics is about philosophy. If you look at different parties [...], they have different views about how our society should be run and what is important in our society. They are value-based philosophical views", Glover observed. Researchers on the other hand look at the data, and remove value aspects as much as possible. Advisors should therefore strive for even-handedness. "It is preferable if you are a neutral person in terms of political alignment, or even adherence to any particular stance”, Gannon advised.

But even in the most enlightened democracies, scientists should not kid themselves in thinking they can win the day with mere evidence. "We scientists know that science advice is laudable, and it should be based on evidence, but science policy makers often do not share that view. They live in a world of opinion and ideology, and that is what we must keep in mind", said Rush Holt, a former US senator and physicist who is now CEO of the American Association for the Advancement of Science (AAAS), at the World Science Forum in Budapest in 2015. He stated that offering a science perspective on issues that politicians might not consider as science is where the great need is. "Policy makers do not think of science frequently or crave scientific advice. They do not even know what to ask", he said.

He had warnings for science advisors too: "Policy makers understand that scientific advice is not a substitute for policy. Anyone who does not understand that will be ignored or dismissed", Holt said. His views are supported by Naledi Pandor, the South African minister for science and technology: "It is important that you are presenting information which can be assessed or evaluated. But if someone approaches you as a politician and says I have the answer and you must take it. That sets up a problematic relationship".

"Science can explain the consequences of inaction, or the likelihood of technological solutions", Gluckman concluded. "In the end these are fundamentally policy decisions of governments weighing up all sorts of trade-offs, including whether they will get re-elected or not". Science can and should have an influence on policy, but scientists should recognize that this will happen in a political realm. 